Man and Nature

MAN AND NATURE

L'homme et la nature

L'HOMME ET LA NATURE

\title{
The Canonized Forefathers and the Household of Man: Burke's Reflections on the Revolution in France and Wordsworth's 'Michael'
}

\section{Anne McWhir}

Volume 10, 1991

URI : https://id.erudit.org/iderudit/1012629ar

DOI : https://doi.org/10.7202/1012629ar

Aller au sommaire du numéro

Éditeur(s)

Canadian Society for Eighteenth-Century Studies / Société canadienne d'étude du dix-huitième siècle

ISSN

0824-3298 (imprimé)

1927-8810 (numérique)

Découvrir la revue

Citer cet article

McWhir, A. (1991). The Canonized Forefathers and the Household of Man: Burke's Reflections on the Revolution in France and Wordsworth's 'Michael'. Man and Nature / L'homme et la nature, 10, 121-131.

https://doi.org/10.7202/1012629ar

Copyright (c) Canadian Society for Eighteenth-Century Studies / Sociéte canadienne d'étude du dix-huitième siècle, 1991
Ce document est protégé par la loi sur le droit d'auteur. L'utilisation des services d'Érudit (y compris la reproduction) est assujettie à sa politique d'utilisation que vous pouvez consulter en ligne.

https://apropos.erudit.org/fr/usagers/politique-dutilisation/ 


\section{The Canonized Forefathers and the Household of Man: Burke's Reflections on the Revolution in France and Wordsworth's 'Michael'}

There are many obvious reasons to dissociate the early Wordsworth from Edmund Burke's Reflections on the Revolution in France. Wordsworth did so himself: his letter to the Bishop of Llandaff in 1793 emphatically condemns Burke and extols the achievements of the revolutionaries. ${ }^{1}$ His differences with Burke outlast Wordsworth's revolutionary fervour: Burke looks backwards through the eighteenth century to an idealized version of chivalry, whereas in the 1805 Prelude Wordsworth emphatically leaves behind such visions - 'some old / Romantic tale by Milton left unsung' (I.168-69) - and traces an unmapped path. ${ }^{2}$ Referring in the 1802 Preface to Lyrical Ballads to the 'household of man' (260), he seems to advocate an inclusive and reciprocal sympathy, based on what the old shepherd Michael calls 'links of love' ('Michael,' 401) rather than on the links of a Burkean genealogical chain of duty and power. Neither father, priest, squire nor king and dependent on none of them, the poet in the household of man claims to be a 'man speaking to men' (255), celebrating a humanized science and a society integrated through the exercise of imagination.

Wordsworth's vision seems powerfully democratic. Burke's political commitment, on the other hand, is aristocratic and conservative, articulated in impassioned, dreamlike, quasi-religious language. His vast overview of history, law, and social relations has little interest in those whose hearths, sepulchres or altars cannot be clearly identified with the interests of established, landed power. Burke takes little account of factory workers, prodigals, dissenters - or women except as the objects of an enlivening chivalry. When he asks rhetorically, '[am I] seriously to felicitate a madman, who has escaped from the protecting restraint and wholesome darkness of his cell, on his restoration to the enjoyment of light and liberty?' (6), he demonstrates an attitude incompatible with much of the literature of the 1790 s - from Gothic irrationality to the eccentricity of some of the poems in Lyrical Ballads. Wordsworth's house- 
hold of man, in which science is transfigured and humanized by the power of poetic imagination, seems far more inclusive than Burke's hierarchical version of the great household of the nation.

But Wordsworth's praise of Burke in the 1850 Prelude is well known:

Could a youth, and one

In ancient story versed, whose breast had heaved

Under the weight of classic eloquence,

Sit, see, and hear, unthankful, uninspired? (VII.540-43)

And even in the 1790s there are affinities between Wordsworth and Burke. Writing about fragments associated with 'The Ruined Cottage,' Geoffrey Hartman comments on 'a providential "compact" between imagination and the things of this world, ... strengthened in Wordsworth by Edmund Burke's view of the social principle as a "great primeval contract ... connecting the visible and invisible world."' This emphasis on 'political continuity' is, according to Hartman, 'the very view which ... Wordsworth had explicitly denounced in his "Letter to Bishop Landaff" [sic] (1793). ${ }^{3}$ Wordsworth's interest in continuity - social, generational and literary rather than explicitly political - is apparent in the Preface to Lyrical Ballads and is dominant in 'Michael' (1800). In this paper I am concerned with the relationship of Wordsworth's early poetry to a discourse of continuity, represented by Burke's Reflections. When Wordsworth writes in the Preface to Lyrical Ballads about the 'household of man,' he is not suggesting a radical alternative to hierarchical authority. The Poet of the Preface, like Michael at the centre of his pastoral and patriarchal household, is a version of Wordsworth himself, a literary counterpart to the 'canonized forefathers ${ }^{4}$ of Burke's political myth.

In Burke's Reflections on the Revolution of France these canonized forefathers mediate between the mythic and mystical rhetoric of Burke's text and the institutions of church and state that it attempts to validate. Figures of permanence and stability, they repress a self-centred individualism and are enshrined in a version of the past constructed as a category of power. Burke condemns the French revolutionaries for hacking the father to pieces and attempting to resurrect him by sorcery (194): equating patricide, superstition, revolution and the 'barbarous philosophy' (171) of a false enlightenment, he permits no revision in the patriarchal canon. But Burke himself exerts his own version of Medea's magic to revive or invent the very forefathers required by his myth of the present. 
Such invention of the past in the image of the present ideal is inevitable and familiar. Yet Burke's emphasis on patriarchy and patrilineal descent may disturb modern readers who lack sympathy with such masculine sublimity. While Burke's central canonized figure is, of course, Marie Antoinette, she is powerless except in the beholder's eye, adorning and obscuring the darker operations of a power she does not exert. For all the sanctity associated with her idealized beauty, virtue and motherhood, children have only one parent who matters politically; the wealth passed on from father to son is an 'entailed inheritance' (119). Burke's ideal family - aristocratic, male-centred, rooted in the land and in the past - escapes history by taking refuge in a myth of time without change, in which momentous individual events like birth and death are caught up in the seamless life of community and nation. The body of the nation, 'composed of transitory parts,' 'is never old, or middle-aged, or young, but in a condition of unchangeable constancy, moves on through the varied tenour of perpetual decay, fall, renovation, and progression' (120) without the memory of birth or the fear of a merely personal death.

The historical context of Burke's version of patriarchy suggests the difficulty of asserting such an ideal by the last decade of the eighteenth century. Early in the century, ideal fathers and ideal households were attached to the land, as Burke still wants them to be in 1790. Addison's Spectator is exemplary in this respect, his estate a microcosm of the nation and a figure for conservative political ideology:

[He was] born to a small Hereditary Estate, which, according to the Tradition of the Village where it lies, was bounded by the same Hedges and Ditches in William the Conqueror's Time that it is at present, and has been delivered down from Father to Son whole and entire ... during the Space of six hundred Years. ${ }^{5}$

The emphasis here, like Burke's, is on continuity. Burke, whose mystical version of the patrilineal family has no room for domesticity, insists on an analogy between family and nation, implicitly between patriarchy and patriotism: 'We begin our public affections in our families. ... We pass on to our neighbourhoods, and our habitual provincial connections.... Such divisions of our country as have been formed by habit, and not by a sudden jerk of authority, were so many little images of the great country in which the heart found something which it could fill' (315). The family, like the nation itself, is attached to ancestral land. This ideal, repeatedly asserted throughout the eighteenth century in response to the challenge of social and economic change, is a significant theme in fiction and poetry as well as in explicitly political writing. The Gothic novel's interest in crumbling aristocratic houses, saintly or demonic 
fathers, and corrupt institutions of power is clearly allegorized in some political writing, where castles are, for instance, emblems of the constitution, as they are for both Burke and Hannah More. ${ }^{6}$ An attack on the corrupt power of such a tyrant-father as Manfred in The Castle of Otranto hardly implies an attack on patriarchy: duly respectful of the Glorious Revolution, Walpole celebrates less the defeat of Manfred and the destruction of his castle than the continuance of the rightful patrilineal line through Theodore, whose name means gift of God and who takes his place in the chain of canonical patriarchs.

The family - its house, its land, its patrimony - is inescapably political; and The Castle of Otranto presents a conservative view of revolutionary change, emphasizing in a different context from Burke's the link between father and son. Samuel Johnson, Montesquieu's 1750 translator Thomas Nugent, and Sir Frederic Morton Eden (in The State of the Poor, 1797) all refer to the kingdom or nation as 'the great household,' an extended family governed by patrilineal descent and patriarchal authority. In the Dictionary (1755), Johnson defines 'household' as '[a] family living together, ${ }^{8}$ complicating his disarmingly simple definition by illustrative quotations (beginning with a reference to 'civil blood' in Romeo and Juliet, Prologue, 4) that emphasize political significance. Quoting from Bacon's Advice to Villiers - 'A little kingdom is a great household, and a great household a little kingdom' - Johnson invites us to consider the microcosm of the household in terms of the macrocosm of the kingdom. ${ }^{9}$ In Rasselas, ascribing the same passage in Bacon to Imlac, Nekayah implies a critique of public life, pointing out that in the little kingdom of the household 'Iplarents and children seldom act in concert,' and deploring domestic discord. ${ }^{10}$ This view of the household and state is a satiric variation on a familiar theme: the household or family is the natural, primary social unit, instituted in scripture (e.g. Colossians 3.18-22) and an appropriate model for the state. Goldsmith's benevolent vicar of Wakefield, whom Wordsworth admired, describes his family as ' $t$ t $]$ he little republic to which I gave laws' ${ }^{11}$ - a republic hardly distinguishable from a monarchy. A man's house is his castle; women and children are implicitly his subjects.

The most influential dissenting voice is Locke's. Correcting Sir Robert Filmer's misquotation of the commandment, 'Honour thy father,' to 'Honour thy father and thy mother,' Locke slips back into patriarchal language immediately afterwards: the implications of the Second Treatise take a long time to affect law, family life, and habitual language. ${ }^{12}$ However, Locke shows very clearly how parental authority is exerted only while children are growing up. For this and other reasons he rejects the household/state analogy: 
if [a family] must be thought a monarchy, and the paterfamilias the absolute monarch in it, absolute monarchy will have but a very shattered and short power, when 'tis plain ... that the master of the family has a very distinct and differently limited power, both as to time and extent, over those several persons that are in it ${ }^{13}$

But in spite of such attacks on the analogy, it persists into the late eighteenth century, not only in Burke but in such a work as Hannah More's Village Politics, where Jack, the conservative author's spokesman, explains household organization to his friend Tom: 'the woman is below her husband, and the children are below their mother, and the servant is below his master.' 'But the subject is not below the king,' replies Tom, rejecting like Locke the analogy of household and state (Village Politics, 181). Jack's counter-position, clearly Hannah More's, is a reaffirmation of that analogy: 'My cottage is my castle' (183). The correspondence of God (whose church is the household of faith [Galatians 6.10]) and of father (head of a family resembling a little kingdom more than a republic) is commonplace, no doubt taken to be essentially true by both Tom and Jack. Conservative writers throughout the seventeenth and eighteenth centuries simply extend the implications of such a model, finding its validation in the role of the king - pater-familias and pater patriae, to use Bacon's phrases in his Advice to Villiers.

But Johnson's use of Bacon's triumphant 'great household,' suggests more confidence than some of the other quotations illustrating his definition of 'household.' Passages from Milton, Sprat and Swift evoke Noah's household on an ark afloat between the lost past and the unknown future, riding out the storm, faithful to its destiny. Johnson's households are families of survivors already dispossessed of their land. Their immediate patriarch is neither God nor the King but Noah, a man for all parties - in Milton's words the 'one just Man alive.' Johnson quotes Milton's version of God's command that Noah 'save himself and household' from doom (Paradise Lost XI. 820). Then he quotes a passage on the 'household of faith' from Sprat's sermons: 'in the first ages of the world, 'twas sometimes literally no more than a single household, or some few families.' Finally, the ark of the righteous household tossed on the waters of faithlessness and ignorance becomes entirely figurative in a quotation from Swift's early 'Ode to the Athenian Society' (1691). Here a war is an inundation, during which, says Swift, 'Learning's little household did embark,/ With her world's fruitful system in her sacred ark. $^{14}$

All these beleaguered households shut up tight against the outside world, saving remnants of faith and learning, waiting for the flood to 
recede, take us a long way from proud theories of religious and political patriarchy in the seventeenth century. But they may recall Sir Robert Filmer's conviction in 1680 that all regal power could trace its origin back to 'some one of the sons or nephews of Noah. ${ }^{15}$ Images of a conservative ideal, they offer hope that the deluge of war, innovation, anarchy or commerce will end, and that the world will begin again, its stable hierarchy intact. If the sacred ark holds an exemplary patriarchal household, however, its survival is uncertain by the end of the eighteenth century. As the household is to the waters of chaos, so is England to France, health to disease, tradition to the glare of enlightenment; Burke undertakes 'to preserve while they can be preserved pure and untainted, the ancient, inbred integrity, piety, good nature, and good humour of the people of England, from the dreadful pestilence which beginning in France, threatens to lay waste the whole moral, and in a great degree the whole physical world ..... ${ }^{16}$

Burke's encouragement to conservative social order comes late. By the end of the eighteenth century Wordsworth's explanation of the decline of 'estatesmen' in his Guide through the District of the Lakes is a representative account of changing family and social patterns. ${ }^{17}$ The structure of the household, great and small, becomes more fragmented late in the century, less vertically cohesive, less bound to ideals of continuity. In Lawrence Stone's words, which echo the elegiac tone of many eighteenth-century writers,

[flewer and fewer knew who their great-grandfathers were, and fewer and fewer cared. ... [The individual] was no longer linked to a piece of property or to tombstones in a graveyard, or to names in a family Bible, and ... he lost his past in the process of achieving his autonomy and self-fulfilment in the present. (The Family, Sex, and Marriage, 397)

One question connects Gray's elegist, excluded from rural community, Goldsmith's poet returning to the deserted village of his birth, Wordsworth's Luke in 'Michael,' forced into exile beyond the sea, and the politics of the revolutionary period: is it possible to 'achieve autonomy and self-fulfilment in the present' and to retain one's past? Characters cut adrift from the home of their fathers - whether grieving like Goldsmith's poet-historian at the moment of separation or fleeing like Godwin's Caleb Williams from a vengeful patriarch - are commonplace in late eighteenth-century literature. The quest for autonomous self-fulfilment sometimes associated with Romanticism is partly a necessary response to historical change. 
Supporters of the French Revolution, condemning the privilege of great families, generally downplay continuing attachment to the land a conservative loyalty - in favour of the contractual community, focussed on the present, on the individual, and on primarily horizontal alliances. In their view, emphasis on the land subordinates the present to past or future and thus to vertical, hierarchical and genealogical structures of power that take precedence over present concerns and needs, particularly those of the oppressed. In his Old Jewry sermon of 1789, for instance, Richard Price provokes Edmund Burke by questioning the connection between personal identity in the present and longstanding attachment to the land:

[B]y our country is meant ... not the soil or the spot of earth on which we happen to have been born ... but ... that body of companions and friends and kindred who are associated with us under the same constitution of government, protected by the same laws, and bound together by the same civil polity. ${ }^{18}$

Our birth place is arbitrary, according to Price, not a symbol of historical continuity like the Spectator's estate. One effect of this is to validate individual association in the present, rather than to replicate the past in each generation: the brotherhood of friends and kindred takes precedence over the fatherhood of those born to power. Genealogy, in this view, would be a paradigm of subordination more than of identity. Price's argument cuts law, constitution and community loose from place and tradition. A castle is only a ruin, not a symbol of continuity.

Burke, on the other hand, continues to celebrate patrilineal descent. Integrity, piety, good nature, and good humour are passed down from father to son, as much a patrimony as the landed estate in the Spectator. Land, moral value, and constitution are inseparable, received from one's ancestors and passed on to posterity in an unbroken line:

In this choice of inheritance we have given to our frame of polity the image of a relation in blood; binding up the constitution of our country with our dearest domestic ties; adopting our fundamental laws into the bosom of our family affections; keeping inseparable, and cherishing with the warmth of all their combined and mutually reflected charities, our state, our hearths, our sepulchres, and our altars. (120)

As in the Spectator's description of the country gentleman, Burke's patrilineal family stretches over time, restraining individual aspiration in the dangerously selfish space between past and future. The behaviour 
of individual fathers and the behaviour of children towards them must, in this view, be governed by the preeminent responsibility of each generation to pass on an intact inheritance.

Wordsworth's household of man, based on love and imagination, is less different than one might think from this version of the great household. 'Home at Grasmere' celebrates 'paternal sway, / One Household, under God, for high and low, / One Family and one mansion' (617-19). Emphasizing in the Preface to Lyrical Ballads the stability of objects in the natural world, Wordsworth attempts to find a continuing place for rustics and the dispossessed in a tradition tied to the land. In spite of his interest in socially marginal groups, then, Wordsworth no less than Burke and Johnson is shoring up fragments against a ruin he deplores.

Burke recalls and reinscribes the central social role of the landed gentry at the very historical moment when other writers hasten or mourn the isolation of generation from generation and of rank from rank; Wordsworth, in spite of his obvious political disagreement with Burke in the revolutionary period, also looks to the land as a way of creating a past to give meaning to the future. Beginning in 1793 by attacking Burke - the 'infatuated moralist' of 'A Letter to the Bishop of Llandaff' (36) - Wordsworth goes on to defend him: by 1818, in 'Two Addresses to the Freeholders of Westmorland,' Burke has already become ' $[t]$ he most sagacious Politician of his age,' one of the heroes of the 1850 Prelude. $^{19}$

We might expect the Wordsworth of 'Michael' (1800), not yet far removed from his revolutionary sympathies, to focus on Michael's son. Luke is, after all, as much a victim as his father of the clash between patriarchal values and social and economic upheaval. But Wordsworth's parable of a prodigal son ends with Michael's death after the destruction of his lineage; in this version of the story, disruption goes too deep to be healed by a feast of reconciliation, because it is a historical disruption, not merely an act based on individual error. Separated from his family first by economic circumstance, then by crime, Luke - like Leonard returning in 'The Brothers' to his brother's unmarked grave is the relic of a ruined household. Cut off from family and thus from identity, he hides from 'ignominy [a bad name in the sense that he has brought dishonour to his father's namel and shame' (445).

While Luke's adventures in his nameless 'hiding-place beyond the seas' (447) might have been the radical focus of Wordsworth's poem, moving beyond patriarchy and genealogy into a new world and a new historical moment, they remain untold. Even in the frame, the father's point of view governs the poem, defining the poet's relationship with his poetic descendants, those 'youthful poets' who will one day be his 'second self.' This insistence on a continuing poetic tradition and a 
patriarchal viewpoint - in spite of Michael's failure to resist the economic and historical severing of his own patriarchal ambition - suggests that Wordsworth's elegiac pastoral is also the beginning of a new, prophetic but conservative myth of the poet.

While he suggests no alternative to patriarchy, Wordsworth does not champion it unambiguously. It persists in uneasy company with Michael's version of the household of man. Doing 'female service' (154) for the infant Luke, Michael exemplifies the dominance and exclusivity of the bond between father and son, displacing the Housewife, Isabel, rather than sharing the care of their child. Patriarchy is reinforced, not undercut, when Michael rocks the cradle of the child who is dearer than his wife 'as with a woman's gentle hand' (158). The Housewife's motives for sending Luke away are more complicated than Michael's patrimonial passion, but we can see her hardly more clearly than we can see Luke: her sorrow at losing her son is cast into the background by Michael's grief; her dreams of glory across the seas, like Luke's adventures and misadventures, are displaced by the Wordsworthian myth of the continuity of the household of man.

In the telling of a tale about an old man and his unfaithful son in 'Michael,' Wordsworth reproduces one version of the frame's implicit tale of a poet and his descendants. The poet of 'Michael' tries to mend the broken genealogy that is both the subject of his tale and the historical context in which his poetic role is formed. Forging links with past and future, the poet creates for himself a place in a generational chain that is already broken, and he leaves us with a tale of betrayal, less homely and far stranger than he claims, its beginning and its ending a heap of unhewn stones. Identifying himself with the heroic but defeated patriarch, Wordsworth ironically identifies 'youthful Poets' (38) with the faithless Luke, who breaks the chain of continuity and patrilineal inheritance.

But while there may be no hope in this poem for Michael or Luke, the poem does not end in despair. '[Y]et the oak is left / That grew beside their door' (479-80): we are back in the world of the Old Testament patriarchs, and in Wordsworth's ideal household the poet himself takes up their role. Luke's fate is unknown, his mother's memory of Richard Bateman not incompatible with an eventual return. Yet like Leonard returning in 'The Brothers,' Luke can only return, if he returns at all, too late. The poet's youthful counterparts are urged to replace the unfaithful Luke, as Wordsworth has replaced the defeated father, inhabiting and enlivening, perhaps haunting with a certain desperation, the abandoned past and its ruined household and sheepfold, signs of the patriarchal covenant. 
Wordsworth's poetic version of the household of man, in which the poet speaks to men from a position of greater insight than theirs, rises out of eighteenth-century history and revolutionary controversy as a metaphor of human community, ostensibly democratic rather than aristocratic, inclusive and classless rather than hierarchical. But Wordsworth's idealization of permanence and continuity in the Preface is, I think, a reinscription in new terms of Burke's rhetoric of continuity in Reflections on the Revolution in France. The power of the 'canonized forefathers' is displaced by the power of the not-yet-canonical poet, as Wordsworth vindicates Johnson's definition of the family: ' $[t]$ hose that descend from one common progenitor; a race; a tribe; a generation.' His household of man, seeking to replace obligation by love and politics by poetry, replicates what it attempts to replace, and Wordsworth's projection of a new literary history, like Burke's version of political history, begins by establishing canonized forefathers.

\section{ANNE MCWHIR \\ University of Calgary}

\section{Notes}

1. The Prose Works of William Wordsworth, ed. W.J.B. Owen and Jane Worthington Smyser (Oxford: Clarendon, 1974), 1: 17-66.

2. Quotations from Wordsworth's poetry are taken from William Wordsworth: The Poems, ed. John O. Hayden, 2 vols. (New Haven and London: Yale UP, 1981) and from The Prelude: 1799, 1805, 1850, ed. Jonathan Wordsworth, M.H. Abrams, and Stephen Gill (New York: Norton, 1979). Quotations from the Preface are from William Wordsworth and Samuel Taylor Coleridge, Lyrical Ballads, ed. R.L. Brett and A.R. Jones (London: Methuen, 1965).

3. Geoffrey H. Hartman, foreword Donald G. Marshall, The Unremarkable Wordsworth (London: Methuen, 1987), 7.

4. Edmund Burke, Reflections on the Revolution in France, ed. with introd. Conor Cruise O'Brien (Harmondsworth: Penguin, 1986), 121.

5. The Spectator, ed. with introd. and notes Donald F. Bond (Oxford: Clarendon, 1965), 1: 1-2.

6. See Burke, 121-22; Hannah More, Village Politics. Addressed to all the Mechanics, Journeymen, and Day Labourers, in Great Britain, Burke, Paine, Godwin, and the Revolution Controversy, ed. Marilyn Butler (Cambridge, CUP, 1984), 181.

7. The State of the Poor, 3 vols. (London, 1797). Montesquieu uses the expression 'the great household' in Book 4.1, The Spirit of the Laws, trans. Thomas Nugent, introd. Franz Neumann, 2 vols. in 1 (New York: Hafner, 1949; rpt. 1966), 29. 
8. Samuel Johnson, A Dictionary of the English Language. 2 vols. (London: W Strahan, 1755; rpt. London: Times Books, 1979).

9. Bacon writes, 'I shall, in a word, and but in a word or two only, put you, Sir, in mind that the King in his own person, both in respect of his household or court, and in respect of his whole kingdom, (for a little kingdom is but as a great household, and a great household as a little kingdom), must be exemplary' (Francis Bacon, Advice to Villiers - the second version, The Works of Francis Bacon, ed. James Spedding [London: Longmans, 1872], 13: 53).

10. Nekayah says, 'if a kingdom be ... a great family, a family likewise is a little kingdom, torn with factions and exposed to revolutions,' Samuel Johnson, The History of Rasselas, Prince of Abissinia, ed. with introd. Geoffrey Tillotson and Brian Jenkins (London: Oxford UP, 1971), 67.

11. The Vicar of Wakefield, ed. Arthur Friedman (London: Oxford UP, 1974), 24. For Wordsworth's attitude, see 'Postscript, 1835,' Prose Works, 3: 252.

12. On Robert Filmer (Patriarcha, 1680) and Locke see Lawrence Stone, The Family, Sex, and Marriage in England, 1500-1800 (New York: Harper, 1977), 152; on Milton and Locke, see Mary Lyndon Shanley, 'Marriage Contract and Social Contract,' The Family in Political Thought, ed. Jean Bethke Elshtain (Amherst: U of Mass P, 1982), 80-95.

13. 'Of Political or Civil Society,' Of Civil Government: Second Treatise, introd. Russell Kirk (Chicago: Gateway, 1955), 67-68.

14. Lines 12-13. This, according to Johnson ('Life of Swift'), is the very poem that induced Dryden to tell Swift, 'Cousin Swift, you will never be a poet.'

15. Patriarcha, Patriarcha and Other Works of Sir Robert Filmer, ed. Peter Laslett (Oxford: Basil Blackwell, 1949), 58.

16. Burke is writing retrospectively about Reflections on the Revolution in France, 'A Letter to A Noble Lord (1796),' Burke, Paine, Godwin and the Revolution Controversy, 55.

17. Prose Works, 2: 224. For discussion of social change in eighteenth-century England, see Dorothy Marshall, Industrial England 1776-1851 (London: RKP, 1973), passim, but especially chapter 4, 'The Changing Social Structure.' By 1801 Wordsworth describes the land-owning poor as 'a class of men ... rapidly disappearing.' Letter to Charles James Fox (14 January), The Letters of William and Dorothy Wordsworth: The Early Years, ed. Ernest de Selincourt, rev. Chester L. Shaver (Oxford: Clarendon, 1967), 1: 315.

18. Richard Price, A Discourse on the Love of our Country, Burke, Paine, Godwin, and the Revolution Controversy, 25.

19. Prose Works, 3: 158. In 'Spiritual Economics: A Reading of Wordsworth's "Michael,"' ELH, 52 (1985): 707-31, Marjorie Levinson mentions an affinity between Burke and Wordsworth: 'Burke's defense of the institution of monarchy involves some of the same premises as those Wordsworth invokes to valorize Michael's lifestyle. The hereditary right of kings ... has, as it were, an acquired legitimacy, comparable to that of the family' $(730, n .10)$. 